\title{
Indirect selection of maize genotypes based on associations between root agronomic and anatomical characters
}

\author{
Ivanildo Nascimento-Júnior ${ }^{1 *}$, Gustavo V. Môro², and Fabíola V. Môro² \\ ${ }^{1}$ Agência Goiana de Assistência Técnica, Extensão Rural e Pesquisa Agropecuária (Emater Goiás), Rua 227A, 331, Setor Leste \\ Universitário, Goiânia, Goiás, Brasil. *Corresponding author (ivanildoramalho@gmail.com). \\ ${ }^{2}$ Universidade Estadual Paulista 'Julio de Mesquita Filho', Faculdade de Ciências Agrárias e Veterinárias, via de acesso Prof. \\ Paulo Donato Castellane, s/n, Jaboticabal, São Paulo, Brasil.
}

Received: 17 August 2017; Accepted: 10 November 2017; doi:10.4067/S0718-58392018000100039

\begin{abstract}
Indirect selection based on highly correlated characters is a common strategy in genetic improvement to quickly and accurately identify genotypes with good agronomic characteristics. The objective of this research study was to quantify existing associations between root agronomic and anatomical characters in maize (Zea mays L.) populations for possible indirect selection. The following agronomic characters were considered: Plant height, ear insertion height, relative ear position, plant lodging, plant breakage, and grain productivity. Measured anatomical characters included total root area, central cylinder area, epidermis thickness, exodermis thickness, endodermis thickness, cortical parenchyma thickness, number of metaxylem vessels, phloem area, cortex thickness, and metaxylem area. The genotypic correlation analysis showed significant associations at the $1 \%$ probability level between the following anatomical and agronomic characters: Endodermis thickness and plant height, exodermis thickness and plant breakage, and exodermis thickness and grain productivity. The canonical analysis of variance showed significant effects by the chi-square test for three of the five canonical pairs. The first canonical pair showed a positive relationship between plant height and total root area (4.142) and a negative relationship with the central cylinder area (-4.080), indicating that genotypes with greater total root area and lower central cylinder area can give rise to larger plants. These results indicated the possibility of an indirect selection of taller or shorter plants in the earlier growth stages using anatomical root characters.
\end{abstract}

Key words: Canonical correlation, correlation between characters, multivariate analysis, Zea mays.

\section{INTRODUCTION}

The root is the organ that is directly related to agricultural production; besides fixing the plant to the soil, it is also responsible for absorbing water and mineral nutrients, which are essential for its growth and development (Atkinson et al., 2014).

The root is different from other organs because it does not consist of vascular bundles. The primary xylem is formed by a central clump along with projections, which spread to the periphery of the vascular cylinder. The phloem forms cords that alternate with the edges of the xylem, which are distributed close to the periphery of the vascular cyclinder and are inside the pericycle. When the xylem does not occupy the whole center of the vascular cylinder, a parenchymatous medulla is formed in this central region, which can harden in the older root regions (Appezzato-da-Glória and Carmello-Guerreiro, 2012). 
With the aim of maximizing the efficiency of improvement programs, studies of correlated characters have been developed to allow plant breeders to proceed faster with the indirect selection of important agricultural crop characteristics (Gompert et al., 2017).

The objective of studies associating the maize (Zea mays L.) root anatomical characters have usually been focused on identifying their relationship with specific soil conditions, such as flooded areas (Magalhães et al., 2009), compacted soils (Bergamin et al., 2010), regions suffering water stress (Chimungu et al., 2014), and soils with an excess of certain chemical elements (Redjala et al., 2011). On the contrary, studies about the association between the anatomical and agronomic characters of the plant itself have not been emphasized.

Due to their strong quantitative genetic heritage, agronomic characters, such as grain productivity, lodging, and plant breakage, are strongly influenced by the environment in contrast to some anatomical characters, such as plants vessel diameters, which are specific to each access and slightly influenced by the environment (Longui et al., 2017).

When a significant correlation exists due to its rapidity, simplicity, and low cost, anatomical characters can be used as indirect characters for selecting different agronomic characters in a plant. The objective of this study was to quantify existing associations between root agronomic and anatomical characters in synthetic maize populations to carry out indirect selection.

\section{MATERIALS AND METHODS}

\section{Evaluation of agronomic characters}

Thirteen synthetic maize populations from the Agricultural and Veterinarian Science Faculty (Di Salvo, 2011) were evaluated in the field during the 2009-2010 summer crop season and the 2010 winter crop season in Jaboticabal county, São Paulo State ( $21^{\circ} 15^{\prime} 17^{\prime}$ ' S, 48 $19^{\prime}$ '20” W; 605 m a.s.l.) and in Campo Alegre de Goiás, Goiás State in the

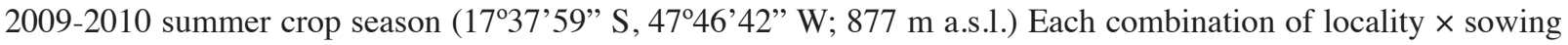
period was considered as a distinct environment for a total of three environments.

The experimental design in each environment was random blocks with three replicates; sample plots consisted of four $5 \mathrm{~m}$ rows in which the two center rows were considered as the sample area. Inter-plant spacing was $0.2 \mathrm{~m}$, inter-row spacing was $0.9 \mathrm{~m}$, and the population was approximately 50 plants per sample plot.

When more than $50 \%$ of the plants in each plot were observed releasing pollen, the following agronomic characters of 10 plants per plot were measured: plant height $(\mathrm{PHe}, \mathrm{cm})$ measured as the distance between the soil and flag leaf, ear insertion height $(\mathrm{EIH}, \mathrm{cm})$, relative ear position (REP) expressed as the relationship between ear insertion height and plant height, lodging (Lod, \%) expressed as the percentage of plants with an inclination angle greater than $45^{\circ}$ in relation to the vertical plane or lying on the soil at harvest, and plant breakage ( $\left.\mathrm{PBr}, \%\right)$ expressed as the percentage of plants broken below the main ear.

After harvest, grain productivity (GP) was evaluated by weighing the grains from each plot, including lodged plants. Humidity was corrected to $13 \%$ and this value was converted to tons per hectare.

\section{Evaluation of root anatomical characters}

The same 13 populations were sown in the Agricultural and Veterinarian Science Faculty of the Universidade Estadual Paulista (UNESP) in Jaboticabal, São Paulo State, in 2014. Populations were under shade screens in 2-L polyethylene bags containing a manufactured substrate of pinus bark and coconut fiber (Bioplant, Minas Gerais, Brazil) and soil, Red Eutrophic Latosoil (Embrapa, 2013), in a 1:1 ratio. Three seeds were sown per bag and later thinned to one plant per bag.

The experimental design was random blocks with nine replicates, and each plastic bag was considered as a plot. The design was selected after observing the variation in sunlight of the shade screens.

Roots were collected when the plants reached the 6-leaf stage (V6), all the soil was removed from the bags, roots were washed in running water, and then cut into approximately $0.5 \mathrm{~cm}$ sections in the middle of the elongation region. Care was taken to collect identical root samples so that less stable anatomical characters could be evaluated.

After collection, the material was fixed for $48 \mathrm{~h}$ in a solution of formaldehyde, acetic acid, and 50\% ethanol (FAA 50) (Johansen, 1940), whose volume corresponded to 10 times the volume of the samples. Tissue samples were later 
dehydrated using an alcoholic battery as described by Johansen (1940), and infiltrating the material with an ethanolxylol series in a 1:1 ratio.

The material was later transferred to aluminium molds with molten paraffin and remained in an oven at $60{ }^{\circ} \mathrm{C}$ for $12 \mathrm{~h}$. The paraffin was changed every $4 \mathrm{~h}$.

The paraffin blocks were mounted using small paper boxes already coated with paraffin. The material of the aluminium molds was duly labeled and placed longitudinally in the center of the boxes.

After the blocks had completely solidified, paraffin ribbon sectioning began with a sliding rotary microtome calibrated to a thickness of $12.5 \mu \mathrm{m}$. The slides remained on a heating plate at $40{ }^{\circ} \mathrm{C}$ to expand the ribbon so that the sections could be better fixed. After the quality of the slides had been confirmed with the optical microscope, they were immersed in xylol to remove the paraffin and then rehydrated using an ethanol-xylol series (3:1) as described by Johansen (1940). The slides were stained with toluidine blue (Sakai, 1973) in an exhaustion chamber for 2 min, washed in running water, and then dried at room temperature.

A drop of rapid mounting medium (Entellan, Merck, Darmstadt, Germany) was placed on the slide to conserve the specimen, which was protected with a cover slip; it was left at room temperature until drying was complete. Slides were photographed using an optical microscope with an attached digital camera. One photograph was taken per slide and root anatomical parameters were evaluated with the help of the Motic Images (version 2.0) analysis program (Motic, Hong Kong, China), calibrated with a microscopic scale, and photographed at the same photographic magnifications.

The following root anatomical characters were evaluated: total root area (TRA, $\left.\mu \mathrm{m}^{2}\right)$, central cylinder area $(\mathrm{CCA}$, $\mu \mathrm{m}^{2}$ ), epidermis thickness (EpT, $\left.\mu \mathrm{m}\right)$, exodermis thickness (ExT, $\left.\mu \mathrm{m}\right)$, endodermis thickness $(\mathrm{EnT}, \mu \mathrm{m})$, and cortical parenchyma thickness $(\mathrm{CPT}, \mu \mathrm{m})$, number of metaxylem vessels $(\mathrm{NMV})$, phloem area $\left(\mathrm{PhA}, \mu \mathrm{m}^{2}\right)$, cortex thickness $(\mathrm{CoT}, \mu \mathrm{m})$, and metaxylem area $\left(\mathrm{MeA}, \mu \mathrm{m}^{2}\right)$. Each epidermis, exodermis, cortical parenchyma, endodermis, and cortex thickness was randomly measured four times. This same procedure was performed for the phloem and metaxylem areas (Figure 1).

Figure 1. Detail of root transverse sections in synthetic maize populations seen under the microscope, identifying the measured organs.
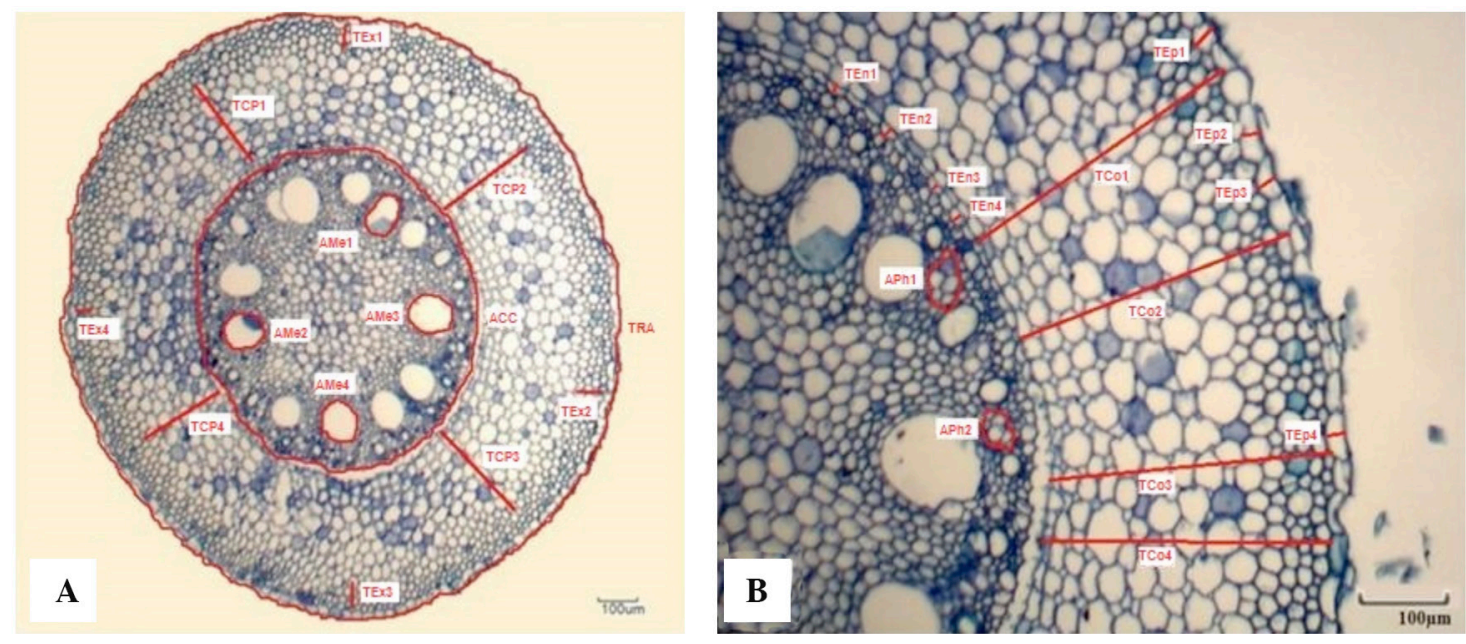

A. Total leaf area (TLA), central cylinder area (CCA), exodermis thickness (ExT1, ExT2, ExT3, and ExT4) and cortical parenchyma thickness (CPT1, CPT2, CPT3, and CPT4), and metaxylem area (MeA1, MeA2, MeA3, and MeA4) at 4X magnification. B. Epidermis thickness (EpT1, EpT2, EpT3. and EpT4), cortex thickness (CoT1, CoT2, CoT3, and CoT4), endodermis thickness (EnT1, EnT2, EnT3, and EnT4), and phloem area (PhA1 and PhA2) at 10X magnification. 


\section{Statistical analyses}

After the evaluation of the root agronomic (G1) and anatomical characters (G2), a joint analysis of variance was carried out and the genetic parameters of both groups (G1 and G2) were estimated. A genotypic linear correlation analysis was also performed within each group.

The assumptions of the ANOVA (Cruz et al., 2012) were verified with studies of multicollinearity between all the evaluated characters, homogeneity of variance by Cochran's and Bartlett's tests (Fuentealba et al., 2016), and normality by the Lilliefors test (Razali and Wah, 2011). For characters that did not fulfill some of the assumptions, data were transformed (Cruz et al., 2012); lodging (Lod) was transformed to $\sqrt{(x)+1}$ and MeA to $\log (\mathrm{x})+1$.

A canonical analysis of variance study verified the association between the G1 and G2 characters, denoting the values of the agronomic (G1 variables) and anatomical characters (G2 variables) as vectors; variables were later rewritten as a linear $\mathrm{U}$ and $\mathrm{V}$ combination to determine the linear combination between $\mathrm{U}$ and $\mathrm{V}$ with the canonical combination to maximize the Corr (U,V) correlation (Cruz et al., 2012). The first canonical correlation $\left(r_{1}\right)$, corresponding to the first canonical pair, was the square root of the first autovalue $\left(r_{1}=\sqrt{ } \lambda_{1}\right)$ and so on for the remaining canonical correlations. The chi-square test (Cruz et al., 2012) was used to test the null hypothesis of the absence of correlation between the two groups of characters. All statistical analyses were performed with the GENES computer program (Cruz, 2013).

\section{RESULTS AND DISCUSSION}

The combined analysis of variance of the agronomic characters showed that the effects of the Genotype $\times$ Environment interaction were nonsignificant at the $5 \%$ level (Table 1), indicating that the relative behavior of the genotypes for the analyzed variables was slightly influenced by the environmental conditions of the field experiments.

Since a significant Genotype $\times$ Environment interaction was not observed in the combined analysis of variance of the agronomic characters (Table 1), a new ANOVA was performed to increase the precision of the canonical correlation analysis using the same number of replicates for the two groups. The number of selected replicates was nine for the agronomic characters when one replicate was considered for each block and environmental combination; this coincided with the number of selected replicates for the anatomical characters (Table 2).

A significant difference at the $1 \%$ level was observed in the source of population variation for the agronomic characters Lod, PBr, PHe, EIH, and GP. A 1\% probability was observed for the root anatomical characters TRA, CCA, EpT, ExT, NMV, PhA, CoT and MeA, as well as a 5\% probability for EnT (Table 2), indicating the existence of variability in the study material. Since the REP character showed a nonsignificant difference between populations, it was eliminated from the estimates of genetic parameters and canonical correlation analysis.

As observed in the present study, high values of coefficients of variation (CV\%) of the characters Lod and $\mathrm{PBr}$ were also detected by other authors when they evaluated these characters by counting plants (Gomes et al., 2010). Ferreira et al. (2009) observed CV\% of $42.0 \%$ and $41.4 \%$ for the percentage of lodged and broken plants, respectively. The CV\% of the anatomical characters TRA and CCA showed values greater than $20 \%$, which would be a high variation in agricultural experiments according to Pimentel-Gomes (2009). However, there are no similar studies in the literature for comparison. This result would tend to be more common in anatomical structures due to the unit used to measure these characters $\left(\mu \mathrm{m}\right.$ and $\left.\mu \mathrm{m}^{2}\right)$, which is different from the units used in agricultural trials.

Table 1. Mean squares and significances of the joint analysis of variance of agronomic characters in 13 maize populations.

\begin{tabular}{|c|c|c|c|c|c|c|c|}
\hline Source of variation & $\mathrm{DF}$ & $\mathrm{PHe}$ & $\mathrm{EIH}$ & REP & Lod & $\mathrm{PBr}$ & GP \\
\hline Blocks/environment & 6 & $85.85^{\mathrm{ns}}$ & $50.40^{\text {ns }}$ & $0.01^{\mathrm{ns}}$ & $0.88^{\text {ns }}$ & $63.49^{\text {ns }}$ & $1.05^{\mathrm{ns}}$ \\
\hline Environment (E) & 2 & $13418.01^{\mathrm{ns}}$ & $3729.06^{\mathrm{ns}}$ & $0.01^{\mathrm{ns}}$ & $1.96^{\mathrm{ns}}$ & $2734.01^{\mathrm{ns}}$ & $39.78^{\mathrm{ns}}$ \\
\hline Genotype (G) & 12 & $1387.67^{\mathrm{ns}}$ & $845.68^{\mathrm{ns}}$ & $0.01^{\mathrm{ns}}$ & $3.44^{\mathrm{ns}}$ & $72.92^{\text {ns }}$ & $3.75^{\mathrm{ns}}$ \\
\hline Interaction $\mathrm{G} \times \mathrm{E}$ & 24 & $268.78^{\mathrm{ns}}$ & $149.65^{\mathrm{ns}}$ & $0.01^{\mathrm{ns}}$ & $0.63^{\mathrm{ns}}$ & $36.03^{\mathrm{ns}}$ & $0.26^{\mathrm{ns}}$ \\
\hline Mean & & $205.65^{\mathrm{ns}}$ & $118.19^{\mathrm{ns}}$ & $0.58^{\mathrm{ns}}$ & $2.07^{\mathrm{ns}}$ & $7.04^{\mathrm{ns}}$ & $3.97^{\mathrm{ns}}$ \\
\hline Mean error & 72 & $167.99^{\text {ns }}$ & $93.53^{\mathrm{ns}}$ & $0.01^{\mathrm{ns}}$ & $0.72^{\text {ns }}$ & $22.51^{\mathrm{ns}}$ & $0.20^{\mathrm{ns}}$ \\
\hline $\mathrm{CV}, \%$ & & $6.30^{\mathrm{ns}}$ & $8.18^{\mathrm{ns}}$ & $9.78^{\mathrm{ns}}$ & $40.96^{\mathrm{ns}}$ & $67.37^{\mathrm{ns}}$ & $11.22^{\mathrm{ns}}$ \\
\hline
\end{tabular}

DF: Degree of freedom; PHe: plant height $(\mathrm{cm})$; EIH: ear insertion height $(\mathrm{cm})$; REP: relative ear position (cm); Lod: lodging (transformed data); PBr: Plant breakage (\%); GP: grain productivity $\left(\mathrm{t} \mathrm{ha}^{-1}\right)$; CV: coefficient of variation.

ns: Nonsignificant at the 0.05 probability level by the $\mathrm{F}$ test. 
Table 2. Mean squares and significances of the agronomic and anatomical characters in 13 maize populations.

\begin{tabular}{|c|c|c|c|c|c|c|c|}
\hline \multirow[b]{2}{*}{ Source of variation } & \multirow[b]{2}{*}{$\mathrm{DF}$} & \multicolumn{6}{|c|}{ Agronomic characters } \\
\hline & & $\mathrm{PHe}$ & EIH & REP & Lod & $\mathrm{PBr}$ & GP \\
\hline Blocks & 8 & 3418.88 & 970.08 & 0.002 & 1.16 & 731.12 & 10.73 \\
\hline Populations & 12 & $1387.73^{* *}$ & $845.67^{* *}$ & $0.003^{\text {ns }}$ & $3.44^{* *}$ & $72.92^{* *}$ & $3.75^{* *}$ \\
\hline Residual & 96 & 202.54 & 112.13 & 0.003 & 0.70 & 30.24 & 0.21 \\
\hline Mean & & 205.65 & 118.19 & 0.57 & 2.07 & 7.04 & 3.97 \\
\hline \multirow[t]{3}{*}{$\mathrm{CV}, \%$} & & 6.92 & 8.96 & 9.93 & 40.29 & 78.08 & 11.64 \\
\hline & & \multicolumn{6}{|c|}{ Anatomical characters } \\
\hline & & TRA & $\mathrm{CCA}$ & EpT & & ExT & СРТ \\
\hline Blocks & 8 & $4.8 \times 10^{9}$ & $5.1 \times 10^{8}$ & 19.75 & & 637.73 & 6262.57 \\
\hline Populations & 12 & $2.9 \times 10^{9 * *}$ & $3.0 \times 10^{8 * *}$ & $42.57^{* *}$ & & $1112.01^{* *}$ & $5936.13^{* *}$ \\
\hline Residual & 96 & $8.5 \times 10^{8}$ & $8.5 \times 10^{7}$ & 5.21 & & 183.15 & 1040.68 \\
\hline Mean & & $1.33 \times 10^{5}$ & $4.0 \times 10^{4}$ & 13.56 & & 73.62 & 216.37 \\
\hline \multirow[t]{3}{*}{$\mathrm{CV}, \%$} & & 21.94 & 23.12 & 16.83 & & 18.38 & 14.91 \\
\hline & & \multicolumn{6}{|c|}{ Anatomical characters } \\
\hline & & EnT & NMV & $\mathrm{PhA}$ & & CoT & $\mathrm{MeA}$ \\
\hline Blocks & 8 & 6.96 & 20.44 & $2.4 \times 10^{5}$ & & $1.0 \times 10^{4}$ & 0.06 \\
\hline Populations & 12 & $4.36^{*}$ & $15.88^{* *}$ & $1.4 \times 10^{5 * *}$ & & $8.0 \times 10^{3 * *}$ & $0.04^{* *}$ \\
\hline Residual & 96 & 1.97 & 3.03 & $2.7 \times 10^{4}$ & & $1.5 \times 10^{3}$ & 0.01 \\
\hline Mean & & 11.83 & 11.19 & 1198.59 & & 286.49 & 4.93 \\
\hline $\mathrm{CV}, \%$ & & 11.86 & 15.55 & 13.69 & & 13.81 & 1.95 \\
\hline
\end{tabular}

DF: Degree of freedom; PHe: plant height $(\mathrm{cm})$; EIH: ear insertion height $(\mathrm{cm})$; REP: relative ear position ( $\mathrm{cm})$; Lod: lodging (transformed data); PBr: plant breakage (\%); GP: grain productivity $\left(\mathrm{t} \mathrm{ha}^{-1}\right)$; TRA: total root area $\left(\mu \mathrm{m}^{2}\right)$; CCA: central cylinder area $\left(\mu \mathrm{m}^{2}\right)$; EpT: epidermis thickness $(\mu \mathrm{m})$; ExT: exodermis thickness $(\mu \mathrm{m})$; CPT: cortical parenchyma thickness $(\mu \mathrm{m})$; EnT: endodermis thickness $(\mu \mathrm{m})$; NMV: number of metaxylem vessels; PhA: phloem area $\left(\mu \mathrm{m}^{2}\right)$; CoT: cortex thickness $(\mu \mathrm{m})$; MeA: metaxylem area (transformed data); CV: coefficient of variation. *, "* Significant at the 0.05 and 0.01 probability levels, respectively, by the $\mathrm{F}$ test; ns: nonsignificant.

The values of the genotypic quadratic components were higher than those of the environmental variance for all the character means, indicating a high genetic variability in the populations. The exception was the lodging character (Lod) in which the genotypic quadratic component was less than the environmental variance (Table 3).

Genotypic determination coefficient values for plots varied from $13.56 \%(\mathrm{PBr})$ to $64.78 \%$ (GP) for the agronomic characters and from $11.90 \%$ (EnT) to $44.36 \%$ (EpT) for the anatomical characters (Table 3), demonstrating a high possibility of success to select GP. This coefficient represents the tendency to maintain the phenotypical superiority of the genotypes in the different evaluated environments; as the genotypic determination coefficient increases at the plot level, the interference of the Genotype $\times$ Plot interaction in the population decreases (Laviola et al., 2014).

For the genetic variation coefficients $(\mathrm{CVg})$, most of evaluated characters showed a good indication of genetic potential; according to Rodrigues et al. (2011), these should be greater than 7\%, except for characters PHe, EnT and MeA, which had values of $5.58 \%, 4.36 \%$, and $1.14 \%$, respectively (Table 3 ).

For the ratio between genetic variation and environmental coefficients $(\mathrm{CVg} / \mathrm{CVe}), \mathrm{GP}$ was the only character exhibiting a ratio greater than 1 , which is a favorable condition for selection (Cruz et al., 2012) together with the high genotypic quadratic component (Table 3).

Significant genotypic correlations (Table 4) were observed at the $5 \%$ level between the agronomic and anatomical characters EpT and Lod (0.62), ExT and Lod (0.66), MeA and Lod (-0.67), MeA and PBr (-0.65), and MeA and GP (0.68); significant genotypic correlations at the $1 \%$ level were between EnT and PHe (0.83), ExT and PBr (0.82), and ExT and GP (-0.76). This makes indirect selection in the early stages of plant development viable, which is aimed at increasing GP and tolerance to Lod and PBr. A positive correlation between ExT and Lod and ExT and $\mathrm{PBr}$ and a negative correlation between ExT and GP indicate that plants with smaller ExT can be more tolerant to Lod and PBr, resulting in higher GP. This can be because the exodermis, just like the endodermis, has the function of protecting the penetration of microorganisms and is also responsible for regulating the absorption of water and mineral nutrients into the plant. This reduces the passage of water through the apoplast, the spaces between cells, and thus gives priority to water flow via the symplast through the cell cytoplasm (Raven et al., 2014). This can delay the use of these elements by the plant, thus making them more sensitive and unproductive. 
Table 3. Estimates of the phenotypic quadratic components for population means $\left(\phi_{\mathrm{F}}\right)$, components of mean environmental variance $\left(\sigma^{2} \mathrm{Ex}\right)$, genotypic quadratic components $\left(\phi_{\mathrm{G}}\right)$, genotypic determination coefficients for plots $\left(\mathrm{H}^{2}\right)$, genetic variation coefficients $\left(\mathrm{CV}_{\mathrm{g}}\right)$, and ratio between genetic variation and environmental coefficients $\left(\mathrm{CV}_{\mathrm{g}} / \mathrm{CV}_{\mathrm{e}}\right)$ of the characters evaluated in 13 maize populations.

\begin{tabular}{|c|c|c|c|c|c|}
\hline \multirow[b]{2}{*}{ Parameters } & \multicolumn{5}{|c|}{ Agronomic characters } \\
\hline & $\mathrm{PHe}$ & EIH & Lod & $\mathrm{PBr}$ & GP \\
\hline$\phi_{\mathrm{F}}$ & 154.19 & 93.96 & 0.38 & 8.10 & 0.42 \\
\hline$\sigma^{2} \mathrm{Ex}$ & 22.50 & 12.46 & 0.78 & 3.36 & 0.02 \\
\hline$\phi_{\mathrm{G}}$ & 131.69 & 81.50 & 0.30 & 4.74 & 0.39 \\
\hline $\mathrm{H}^{2}$ & 39.40 & 42.09 & 30.31 & 13.56 & 64.78 \\
\hline $\mathrm{CV}_{\mathrm{g}}$ & 5.58 & 7.64 & 26.57 & 30.92 & 15.79 \\
\hline \multirow{3}{*}{$\mathrm{CV}_{\mathrm{g}} / \mathrm{CV}_{\mathrm{e}}$} & 0.81 & 0.85 & 0.66 & 0.40 & 1.36 \\
\hline & \multicolumn{5}{|c|}{ Anatomical characters } \\
\hline & TRA & $\mathrm{CCA}$ & EpT & ExT & $\mathrm{CPT}$ \\
\hline$\phi_{\mathrm{F}}$ & $3.2 \times 10^{8}$ & $3.3 \times 10^{7}$ & 4.73 & 123.54 & 659.57 \\
\hline$\sigma^{2} \mathrm{Ex}$ & $9.5 \times 10^{7}$ & $9.5 \times 10^{6}$ & 0.58 & 20.35 & 115.63 \\
\hline$\phi_{\mathrm{G}}$ & $2.3 \times 10^{8}$ & $2.3 \times 10^{7}$ & 4.15 & 103.19 & 543.94 \\
\hline $\mathrm{H}^{2}$ & 21.33 & 21.51 & 44.36 & 36.04 & 34.33 \\
\hline $\mathrm{CV}_{\mathrm{g}}$ & 11.43 & 12.11 & 15.03 & 13.80 & 10.78 \\
\hline \multirow[t]{3}{*}{$\mathrm{CV}_{\mathrm{g}} / \mathrm{CV}_{\mathrm{e}}$} & 0.52 & 0.52 & 0.89 & 0.75 & 0.73 \\
\hline & \multicolumn{5}{|c|}{ Anatomical characters } \\
\hline & EnT & NMV & $\mathrm{PhA}$ & $\mathrm{CoT}$ & $\mathrm{MeA}$ \\
\hline$\phi_{\mathrm{F}}$ & 0.48 & 1.76 & $1.5 \times 10^{4}$ & 889.01 & $4.2 \times 10^{-3}$ \\
\hline$\sigma^{2} \mathrm{Ex}$ & 0.23 & 0.34 & $3.0 \times 10^{3}$ & 174.04 & $1.0 \times 10^{-3}$ \\
\hline$\phi_{\mathrm{G}}$ & 0.26 & 1.43 & $1.2 \times 10^{4}$ & 714.97 & $3.2 \times 10^{-3}$ \\
\hline $\mathrm{H}^{2}$ & 11.90 & 32.03 & 31.48 & 31.34 & 25.59 \\
\hline $\mathrm{CV}_{\mathrm{g}}$ & 4.36 & 10.68 & 9.28 & 9.33 & 1.14 \\
\hline $\mathrm{CV}_{\mathrm{g}} / \mathrm{CV}_{\mathrm{e}}$ & 0.37 & 0.69 & 0.68 & 0.67 & 0.59 \\
\hline
\end{tabular}

PHe: Plant height $(\mathrm{cm})$; EIH: ear insertion height $(\mathrm{cm})$; Lod: lodging (transformed data); PBr: plant breakage (\%); GP: grain productivity $\left(\mathrm{t} \mathrm{ha}{ }^{-1}\right)$, TRA: total root area $\left(\mu \mathrm{m}^{2}\right)$; CCA: central cylinder area $\left(\mu \mathrm{m}^{2}\right)$; EpT: epidermis thickness $(\mu \mathrm{m})$; TEx: thickness of the exodermis $(\mu \mathrm{m})$; CPT: cortical parenchyma thickness $(\mu \mathrm{m})$, EnT: endodermis thickness $(\mu \mathrm{m})$; NMV: number of metaxylem vessels; PhA: phloem area $\left(\mu \mathrm{m}^{2}\right)$; CoT: cortex thickness $(\mu \mathrm{m}), \mathrm{MeA}$ : metaxylem area (transformed data).

The positive association between the MeA and GP and the negative association between MeA and Lod is probably linked to the xylem function, which is responsible for transporting water and minerals in the plant (Stokke et al., 2013). Plants with larger xylem vessels have higher water flow capacity, a fundamental characteristic for a productive plant.

Table 4. Estimates of genotypic correlations between the variables obtained from 13 synthetic maize populations.

\begin{tabular}{|c|c|c|c|c|c|}
\hline & $\mathrm{PHe}$ & EIH & Lod & $\mathrm{PBr}$ & GP \\
\hline TRA & $0.57^{* *}$ & 0.43 & $-0.48^{*}$ & $0.21^{* *}$ & $0.42^{* *}$ \\
\hline CCA & $0.31^{* *}$ & 0.19 & $-0.59^{*}$ & $0.15^{* *}$ & $0.45^{*}$ \\
\hline EpT & $0.14^{* *}$ & 0.06 & $0.62^{*}$ & $0.10^{* *}$ & $-0.17^{* *}$ \\
\hline ExT & $-0.01^{* * *}$ & 0.20 & $0.66^{*}$ & $0.82^{* * *}$ & $-0.76^{* *}$ \\
\hline CPT & $0.37^{\text {** }}$ & 0.23 & $-0.39^{*}$ & $-0.32^{* * *}$ & $0.58^{* *}$ \\
\hline EnT & $0.83^{* *}$ & 0.59 & $-0.14^{*}$ & $0.36^{* *}$ & $0.12^{* *}$ \\
\hline NMV & $0.11^{* *}$ & 0.07 & $-0.30^{*}$ & $0.11^{* *}$ & $0.41^{* * *}$ \\
\hline $\mathrm{PhA}$ & $-0.11^{* * *}$ & -0.07 & $0.29^{*}$ & $0.01^{* *}$ & $0.16^{* *}$ \\
\hline $\mathrm{CoA}$ & $0.42^{* *}$ & 0.27 & $-0.51^{*}$ & $-0.04^{* * *}$ & $0.42^{* *}$ \\
\hline $\mathrm{MeA}$ & $-0.23^{* *}$ & -0.56 & $-0.67^{*}$ & $-0.65^{* *}$ & $0.68^{* * *}$ \\
\hline
\end{tabular}

TRA: Total root area $\left(\mu \mathrm{m}^{2}\right)$, CCA: central cylinder area $\left(\mu \mathrm{m}^{2}\right)$, EpT: epidermis thickness $(\mu \mathrm{m})$, ExT: exodermis thickness $(\mu \mathrm{m})$, CPT: cortical parenchyma thickness $(\mu \mathrm{m})$, EnT: endodermis thickness $(\mu \mathrm{m})$, NMV: number of metaxylem vessels, PhA: phloem area $\left(\mu \mathrm{m}^{2}\right)$, CoT: cortex thickness $(\mu \mathrm{m})$, MeA: metaxylem area, PHe: plant height $(\mathrm{cm})$, EIH: ear insertion height $(\mathrm{cm})$, Lod: lodging $(\%)$, PBr: plant breakage $(\%)$, GP: grain productivity $\left(\mathrm{t} \mathrm{ha}^{-1}\right)$.

${ }^{*},{ }^{* *}$ Significant at the 0.05 and 0.01 probability levels, respectively, by the t-test, and the remaining values are nonsignificant. 
The canonical analyses of variance showed significant effects by the chi-square test for three of the five canonical pairs. Coefficients were significant at the $5 \%$ level for the first, second, and third pairs, indicating that modifying the group of anatomical characters can influence the group of agronomic characters. Therefore, one group or another can be considered for selection for genetic improvement (Table 5).

The first canonical pair showed a positive relationship between PHe and TRA and a negative relationship with CCA, indicating that genotypes with greater TRA and lower CCA can give rise to larger plants (Table 5). This characteristic is useful for indirect selection, whose objective is to change the height of a genotype. It is difficult to harvest because of its size, but it already has good agronomic characteristics for a commercial genotype. Some studies have reported that plants with thinner roots tend to develop better as compared to those with thicker roots. Lynch (2015) comments that plants with a large quantity of thin roots normally present lower metabolic costs of soil exploration that can improve the acquisition of water and nutrients. This is supported by Souza (2009), who comments that thin roots (up to $2 \mathrm{~mm}$ in diameter) are more responsible for the absorption of water and nutrients than thicker roots, whose function is more concerned about fixing the plant in the soil. Wendling et al. (2016) report that plants that have a higher volume of thin roots in their early development stage exhibit greater adaptive capacity in terms of water and nutritional deficit.

The second canonical pair (Table 5) showed a high, positive relationship between EnT/CoT and PHe, indicating that plants with higher EnT and CoT can produce plants with higher PHe. The association between EnT and PHe was also observed in the genotypic correlation analysis and can be related to water regulation to the interior of the plant. On the other hand, the relationship between CoT and PHe can be related to the absorption efficiency of minerals that are important for the plant and result in taller plants. York et al. (2015), comparing the anatomical evolution of the maize root of current varieties with the genotypes of 100 years ago, observed that current genotypes are certainly more efficient in absorbing soil $\mathrm{N}$, have a larger cellular cortex, as well as fewer radicle nodules and longer lateral branches. This emphasizess the need for new research to understand how these root properties can affect the absorption of $\mathrm{N}$ and other nutrients, such as $\mathrm{P}$.

Table 5. Canonical correlations and canonical pairs estimated between the agronomic components of Group I: Plant height (PHe), ear insertion height (EIH), relative ear position (REP), lodging (Lod), plant breakage (PBr), and grain productivity (GP); root anatomical components of Group II: Total root area (TRA), central cylinder area (CCA), epidermis thickness (EpT), exodermis thickness (ExT), cortical parenchyma thickness (CPT), endodermis thickness (EnT), number of metaxylem vessels (NMV), phloem area (PhA), cortex thickness (CoT), and metaxylem area (MeA) in 13 synthetic maize populations.

\begin{tabular}{|c|c|c|c|c|c|}
\hline \multirow[b]{2}{*}{ Characters } & \multicolumn{5}{|c|}{ Canonical pairs } \\
\hline & $1^{\text {st }}$ & $2^{\text {nd }}$ & $3^{\text {rd }}$ & $4^{\text {th }}$ & $5^{\text {th }}$ \\
\hline & \multicolumn{5}{|c|}{ Group I } \\
\hline $\mathrm{PHe}$ & 1.666 & 1.695 & 1.996 & -1.704 & 0.882 \\
\hline EIH & -1.504 & -0.718 & -3.039 & 0.839 & -1.239 \\
\hline Lod & 0.748 & -1.256 & -0.481 & -0.015 & 0.643 \\
\hline $\mathrm{PBr}$ & -0.896 & -0.558 & 0.687 & 0.836 & 1.260 \\
\hline \multirow[t]{2}{*}{ GP } & 0.247 & -0.870 & -0.895 & 1.255 & 1.098 \\
\hline & \multicolumn{5}{|c|}{ Group II } \\
\hline TRA & 4.142 & -0.276 & -0.096 & -4.911 & -0.529 \\
\hline CCA & -4.080 & 0.153 & -1.290 & 4.576 & -0.112 \\
\hline EpT & -0.081 & -0.338 & -0.171 & 2.053 & -1.362 \\
\hline ExT & 0.125 & -0.291 & 0.683 & -1.049 & 0.725 \\
\hline $\mathrm{CPT}$ & -0.370 & 0.020 & -1.416 & 0.079 & 0.583 \\
\hline EnT & -0.829 & 0.504 & -0.072 & -1.461 & 2.166 \\
\hline NMV & 0.609 & 0.148 & 1.019 & -0.058 & 0.687 \\
\hline $\mathrm{PhA}$ & -0.039 & -0.318 & -0.450 & -0.556 & 1.197 \\
\hline CoT & -0.571 & 0.479 & 1.495 & 2.672 & -1.296 \\
\hline $\mathrm{MeA}$ & 1.500 & -0.021 & 1.093 & -0.940 & 0.342 \\
\hline $\mathrm{r}$ & $1.00 *$ & $1.00 *$ & $0.99 *$ & 0.87 & 0.65 \\
\hline GL & 50 & 36 & 24 & 14 & 6 \\
\hline
\end{tabular}

*Significant correlation coefficients from the chi-square test at the 0.05 probability level of a Type I error. 
The negative relationship between CPT and PHe was observed in the analysis of the third canonical pair (Table 5), indicating that plants with thinner cortical parenchyma result in taller plants. A lower CPT causes less water to pass between the root epidermis and the various conducting vessels, thus facilitating its availability to the plant and positively influencing plant development.

\section{CONCLUSIONS}

Based on genetic parameters, the grain productivity characteristic showed high genetic variability. This indicates that it was efficient for selection.

Genotypic correlation analysis showed the possibility of indirect selections in the earlier stages of plant development for lodging, breakage, plant height, and grain productivity through the anatomical characters of the epidermis and exodermis thickness and metaxylem area. The same possibility to select for plant height was also observed from the canonical correlation analysis using total leaf area, central cyclinder area, and cortex and cortical parenchyma thickness. This makes it possible to obtain more precise selection for such agronomic characters in maize genetic improvement programs.

\section{ACKNOWLEDGEMENTS}

We thank the Coordenação de Aperfeiçoamento de Pessoal de Nível Superior (CAPES) for conceding a scholarship to the first author.

\section{REFERENCES}

Appezzato-da-Glória B., e Carmello-Guerreiro, S.M. 2012. Anatomia Vegetal. $3^{\text {ro }}$ ed. Universidade Federal de Viçosa (UFV), Viçosa, Minas Gerais, Brasil.

Atkinson, J.A., Rasmussen, A., Traini, R., Voss, U., Sturrock, C., Mooney, S.J., et al. 2014. Branching out in roots: Uncovering form, function, and regulation. Plant Physiology 166:538-550.

Bergamin, A.C., Vitorino, A.C.T., Lempp, B., Souza, C.M.A., e Souza F.R. 2010. Anatomia radicular de milho em solo compactado. Pesquisa Agropecuária Brasileira 45:299-305.

Chimungu, J.G., Brown, K.M., and Lynch, J.P. 2014. Large root cortical cell size improves drought tolerance in maize (Zea mays L.) Plant Physiology 166:2166-2178.

Cruz, C.D. 2013. Genes - A software for analysis in experimental statistics and quantitative genetics. Acta Scientiarum 35:271-276.

Cruz, C.D., Regazzi, A.J., e Carneiro, P.C.S. 2012. Modelos biométricos aplicados ao melhoramento genético. $4^{\text {th }}$ ed. Universidade Federal de Viçosa (UFV), Viçosa, Minas Gerais, Brasil.

Di Salvo, F. 2011. Obtenção de variedades sintéticas de milho. 28 p. Master dissertation. Universidade Estadual Paulista "Júlio de Mesquita Filho", Faculdade de Ciências Agrárias e Veterinárias, Jaboticabal, São Paulo, Brasil.

Embrapa. 2013. Sistema brasileiro de classificação de solos. $3^{\text {ro }}$ ed. Embrapa, Brasília, Brazil.

Ferreira, J.M., Moreira, R.M.P., e Hidalgo, J.A.F. 2009. Capacidade combinatória e heterose em populações de milho crioulo. Ciência Rural 39:332-339.

Fuentealba, C., Pedresschi, R., Hernandez, I., and Saavedra, J. 2016. A statistical approach for assessing the heterogeneity of Hass avocados subjected to different postharvest abiotic stresses. Ciencia e Investigación Agraria 43:356-365.

Gomes, L.S., Brandão, A.M., Brito, C.H., Moraes, D.F., e Lopes, M.T.G. 2010. Resistência ao acamamento de plantas e ao quebramento do colmo em milho tropical. Pesquisa Agropecuária Brasileira 45:140-145.

Gompert, Z., Egan, S.P., Barrett, R.D.H., Feder, J.L., and Nosil, P. 2017. Multilocus approaches for the measurement of selection on correlated genetic loci. Molecular Ecology 26:365-382. doi:10.1111/mec.13867.

Johansen, D.A. 1940. Plant microtechnique. Mc Graw Hill, New York, USA.

Laviola, B.G., Silva, D.A.S., Juhász, A.C.P., Rocha, R.B., Oliveira, R.J.P., Albrecht, J.C., et al. 2014. Desempenho agronômico e ganho genético pela seleção de pinhão-manso em três regiões do Brasil. Pesquisa Agropecuária Brasileira 49:356-363.

Lynch, J.P. 2015. Root phenes that reduce the metabolic costs of soil exploration: opportunities for 21 st century agriculture. Plant, Cell and Enviroment 38:1775-1784. 
Longui, E.L., Rajput, K.S, Melo, A.C.G., Alves, L.A., and Nascimento, C.B. 2017. Root to branch wood anatomical variation and its influence on hydraulic conductivity in five Brazilian Cerrado species. Bosque 38:183-193.

Magalhães, P.C., Souza, T.C., Pereira, F.J., Castro, E.M., e Parentoni, S.N. 2009. Ciclos de seleção e modificações na anatomia radicular do milho Saracura sob alagamento. Boletim de Pesquisa e Desenvolvimento 14. Embrapa, Sete Lagoas, Minas Gerais, Brasil.

Pimentel-Gomes, F. 2009. Curso de estatística experimental. 15 $5^{\text {th }}$ ed. Escola Superior de Agricultura "Luiz de Queiroz" (ESALQ), Piracicaba, São Paulo, Brasil.

Raven, P.H., Evert, R.F., e Eichorn, S.E. 2014. Biologia vegetal. $8^{a}$ ed. Guanabara Koogan, Rio de Janeiro, Brasil.

Razali, .N.M., and Wah, Y.B. 2011. Power comparisons of Shapiro-Wilk, Kolmogorov-Smirnov, Lilliefors and AndersonDarling tests. Journal of Statistical Modeling and Analytics 2:21-33.

Redjala, T., Zelko, I., Sterckemana, T., Legué, V., and Lux, A. 2011. Relationship between root structure and root cadmium uptake in maize. Environmental and Experimental Botany 71:241-248.

Rodrigues, F., Pinho, R.G.V., Albuquerque, C.J.B., e Pinho, E.V.R.V. 2011. Índice de seleção e estimativa de parâmetros genéticos e fenotípicos para características relacionadas com a produção de milho-verde. Ciência e Agrotecnologia 35:278-286.

Sakai, W.S. 1973. Simple method for differential staining of paraffin embedded plant material using toluidine blue. Stain Technology Journal 43:247-249.

Souza, T.C. 2009. Evolução das características morfoanatômicas nos ciclos de seleção do milho 'Saracura' sob encharcamento intermitente. 94 p. MSc dissertation. Universidade Federal de Lavras, Departamento de Agricultura, Lavras, Minas Gerais, Brasil.

Stokke, D., Wu, Q., and Han, G. 2013. Introduction to wood and natural fiber composites. John Wiley and Sons, New Jersey, USA.

Wendling, I., Stuepp, C.A., and Zuffellato-Ribas, K.C. 2016. Araucaria clonal forestry: Types of cuttings and mother tree sex in field survival and growth. Cerne 22:19-26.

York, L.M., Galindo-Castañeda, T., Schussler, J.R., and Lynch, J.P. 2015. Evolution of US maize (Zea mays L.) root architectural and anatomical phenes over the past 100 years corresponds to increased tolerance of nitrogen stress. Journal of Experimental Botany 66:2347-2358. 